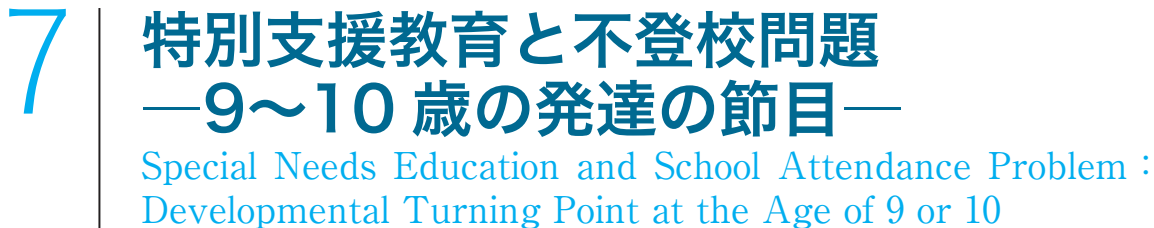

\section{三木裕和 ${ }^{* 1,2}$ \\ Hirokazu Miki}

Key words：特別支援教育/不登校 $/ 9 \sim 10$ 歳の発達の節目

不登校問題を 9〜10 歳の発達の質的転換期を視野に, 障害との関連を念頭に置いて教育学 的に検討した。この質的転換期には抽象的論理的思考が獲得され，学習活動だけでなく，実 行機能などにも变化が現れるが, この発達課題が不登校問題と関連している.「社会性の学 習」や「ほめて育てる」ことは, ときに不適応行動を招くことがあり, 教育方法としては慎 重な吟味が必要だ. 形成的自己評価をめざした学校教育が必要であり, 文化, 科学, 芸術の 習得と内面化を通しての自己変革が求められている.

\section{はじめに}

文部科学省初等中等教育局児童生徒課は, 毎年 度,「児童生徒の問題行動・不登校等生徒指導上の 諸課題に関する調査結果について」を公表してい るが, それによると, 不登校は小学校低学年から発 生し, $3 \sim 4$ 年生頃に若干の増加傾向を示した後, 中学校入学と同時に著しい増加に転じる. 本稿で は, 小学校 3〜 4 年生頃, つまり, 9 10 歳頃の発 達の質的転換期を視野に，障害との関連を念頭に 置いて, 不登校問題の教育学的検討を試みる.

\section{9〜10 歳の発達の節目}

子どもが発達途上で出会う節目として, 以前か ら 9〜10歳が注目されてきた。当初は，ろう児が

\footnotetext{
*1 鳥取大学地域学部地域学科

（ T680-8551 鳥取県鳥取市湖山町南 4-101）

E-mail : hmiki@tottori-u.ac.jp

*2 鳥取大学附属特別支援学校

DOI : 10.2490/jjrmc.56.476
}

小学校中学年の教材理解に強い困難を示すことか ら，それが「9歳の壁」として捉えられていたのた が，その後，ろう児に限らず，広く子ども一般の発 達において, この時期の学力不振が認められ, 発 達の質的転換期の観点から実践研究が取り組まれ るようになった ${ }^{1,2)}$.

9〜10 歳の発達の節目は, 端的にいえば, 抽象的 論理的思考の獲得である。これによって，「目にみ えない抽象的事項」を取り扱うことができるように なる. 日常生活では自然発生的に獲得されること のない小数や分数の概念など, 体系的な教育によっ て初めて習得されるものがこれにあたるが, これら 科学的概念が 9 10 歳の発達のベンチマークであ る.

かけ算, わり算という演算は, それを獲得した者 からみればきわめて容易な操作と映るが，同種の 量を取り扱う足し算, 引き算とは異なり, 異種の単 位操作を必要とすることから，「本質的に異なった 演算」とみなされる。例えば, 「3人の子どもに 4 個のアメを配る」課題で, 4 個 +4 個 +4 個という 
足し算は同種を扱う演算であるが, かけ算では, 個 数 $\times$ 人数 $=$ 個数となる. 生活的概念としての足し 算ではなく, 科学的概念としてのかけ算を発想で きるかどうかは「九九を唱える」と同じではない.

描画活動においても質的変化が認められる。 そ れまでの「感じたとおりに描く絵」から「考えて描 く絵」への発展であり, 描画におけるリアリズムの 導入といえる. 感じたままの描画では,「家より大 きなお父さん」が描かれたりするが，論理性に支え られた表現ではそれがみられなくなる。「家の中で 寝転ぶ妹」のような透視画も消失する．表現に意 図が織り込まれ，手法にも工夫がみられるようにな $ろ^{3)}$. 描画活動の質的発展は，それまでほとんどの 子どもが「絵を描くのが好き」だったのに対して, 「上手に描けないから, 図画工作は嫌い」と答える 子どもが生まれる.

抽象的思考の獲得は実行機能とも深くかかわっ ている. 実行機能とは, 課題を計画性, 論理性を もってやり遂げる機能であるが，例えば，「1日全 体を視野に入れた行事計画を立て，それをやり遂 げることができる」という能力を指す，小学校高学 年になるとそれが備わるので, 行事の立案運営を 任されることもあり, 実行機能の発揮が当該児童 にとって手応え, 喜びをもたらす. 9〜10 歳の発達 に困難のある場合, 計画性, 論理性に弱さがあるた め,「最後までやり遂げる」ことが難しく, その理由 を「やる気のなさ」など精神論に求められることが 多く，人格的評価に結びつきやすい.

このように, 9〜10 歳の発達の節目は, 人間発達 にとって重要な意味をもつものであるが, それゆえ にこそ，ここに「できなさ」のある览童には特別の 負荷がかかることを関係者はよく承知しておかな ければならない。軽度知的障害や自閉症スペクト ラム (以下, 自閉症) など, 一部の発達障害児に とって「勉強がわからない」という訴えは, 決して 意学や努力不足ではない. 周囲の子どもたちが
9〜10 歳の節目を超えていく中での孤立感は深い.

「勉強がわからない」という自覚は学校生活へ の強い不適応感を招き, 不登校の重要な要因とな る. 友だちとの良好な人間関係があったとしても， それで解消される性質のものではない. 質的転換 期の学習困難を障害との関連で捉え, 教育内容, 教育方法, 教育環境の改善をもって臨むことが求 められる. 小学校中学年で特別支援学級への転籍 が多いことはこれと関連するものであろうが，「で きない子」が通常の学級から排除されるというダン ピングではなく, 教育権の実質保障の観点からこ の問題は捉えられるべきであろう.

\section{「自己客観視」と 自閉症スペクトラム}

自閉症を「心の理論」から研究したウタ・フリス は，その著書『新訂・自閉症の謎を解き明かす』4) で興味深い事実を紹介している.

自閉症児が, 他者の信念（感情, 意思などを含 む）を推察するのがきわめて不得手であることは， 「誤信念課題」などで明らかとなっているが，自閉 症児がそれをまったく達成しないというわけではな い. 障害のない子どもの場合, 通常 4 5 歳で獲得 されるこの心理機制は, 自閉症においては言語精 神年齢が 10 歳, もしくはそれ以上になった段階で 獲得される. 他者の信念を直感的に理解すること が困難であっても, 補完的学習によってそれは可 能となる. しかし, 「補完的学習によって得られた 心の世界についての認識はいつも崩れやすく, 判 断ミスに陥ることも多い」「障害をかなり埋め合わ せて, 内面の心の世界の役割について原則的には 判っている人々も, 実生活の強い緊張を強いられ る社会的場面では安定が崩れる」とフリスはいう.

この指摘を，9〜10 歳の発達の節目と関連づけ てみよう。自閉症児が抽象的論理的思考の言語精 神年齢に達することで，他者の信念を理解できる 
ようになるとしても，それは直感的理解ではなく， 命題的理解である ${ }^{5)}$. したがって, この他者理解 は，その努力の誠実さにもかかわらず，誤った理解 を導くことが多い.

学校現場でみかける高機能自閉症児において も，9１0 歳の言語精神年齢に達した頃から被害 認知の言説が多く聞かれる。散髪をした翌日に友 人にからかわれると「バカにされた」と興奮して訴 える、親しみを込めたからかいなのか，悪意のある 批評なのかの判断は容易ではないが, 命題的理解 による他者理解は，その言語表現を直接的に理解 することから，悪意を感じ取ることが多い，友だち 同士のコミュニケーションは，音声言語は「からか い」であっても, 表情や語調で親しみを補うという 重層的な表現が多く，思春期には特にその傾向が 強い.このことから, 高機能自閉症の命題的他者 理解は友人関係における強い軋轢を招く．このこ とから，自閉症児においては「嫌われている」「変 人だと思われている」など, 否定的自己像が形成さ れやすい.

9 10 歳の発達的力量が生成する頃に, むしろ 自己有用感が低くなり, 孤立感を強め, 友だち関係 の形成が阻害されるという「発達のアイロニー」が ここにはみられる，自閉症だけでなく，注意欠如・ 多動症 (attention-deficit hyperactivity disorder : ADHD）においても, 自らの行動が学校のルール （学校文化）と衝突する現実を強く自覚し, 責任の 所在が自己にあると考えやすいのもこの時期であ る.この子たちの不登校問題は学校への忌避感だ けでなく, 否定的自己像と孤立感が強く作用して いることを忘れてはならない。

\section{「社会性の学習」の功罪}

「自閉症は社会性の障害である。社会性そのも のを改善させることは困難なので, 社会的適応行 動を習得させることが教育課題の中心である」と
する考えが学校教育でよくみられる，実際の指導 は, 体系的に組織されたSST（ソーシャルスキルト レーニング）を参考にしながらも，むしろ，学校教 育の中で自然発生的に行われる行動指導が一般的 だ.

他者の信念を推測しにくいという特徴は, 相手 の感情や意思を推し量ることができず，他者との 衝突を招く。これを回避するための指導は「ある 状況に対して特定の定式や方法を反復継続的にあ てはめる」指導に傾きやすい ${ }^{6}$.

例えば,「トランポリンの順番を代わってもらっ た場合は，必ず，ありがとうと言おう」という指導 が繰り返される，高機能自閉症児の場合，その場 面で「ありがとう」が言えるようになるものの，そ れが高じると「トランポリンを代わってあげたのに, ○○さんはありがとうと言いません」と激昂したり することがある. 社会的適応行動の機械的習得 が, むしろトラブルの原因となっている.

「それは指導の仕方が未熟なのだ」という意見 もあろう。確かに, 機械的指導でない, 配慮の行き 届いたSSTもある. しかし, 物理的ストーリーと は異なり, 人間の心理的ストーリーは予測がきわめ て困難で, 汎用スキルをあらかじめ用意することは 不可能といってもよい. 自閉症児がビデオ機材の 操作を巧みにこなすのは, 機械の反応が法則性に 基づいており，いつも同じ結果が得られるからで あって, 対象が人間となるとそうはいかない.トラ ンポリンの順番を代わるにしても, 相手によってそ の反応は異なり, それに至る過程, 集団, 教師の声 かけなど, 実に多様な要因が関係しており, 結果は コントロールできない. 社会的衝突を繰り返し, 「へんな奴」と呼ばれ，学校への不適応を示す自閉 症児には，特定の定式や方法にこだわる傾向が強 いことに留意すべきだ.

障害者の権利に関する条約第 17 条は,「全ての 障害者は, 他の者との平等を基礎として, その心身 
がそのままの状態で尊重される権利を有する（Every person with disabilities has a right to respect for his or her physical and mental integrity on an equal basis with others)」と規定している. 自閉 症児にあっては, その心理特性はそのままで尊重 されるべきであり, 自閉症ではない人たちのマ ナー, ルールの強要があってはならない.「ありが とうと言うべきかどうか」は本人の自由であり，そ れは本人が本当に「ありがとう」と思っているかど うかに由来すべきだ，必要なことは，自分の気持 ちを理解してもらうことである. 学校文化との衝 突が不登校につながることだけは避けなければな らない。

\section{「ほめて育てる」の功罪}

「軽度知的障害児や発達障害児は成功体験がそ しく, 自己肯定感が低いので, 成功体験を積ませ て，ほめて育てましょう」というメッセージが専門 家から発せられることが多い，一見，もっともな意 見だが，教育学的には慎重な検討が必要である.

軽度知的障害や発達障害の場合, 自己評価が二 分的評価に陥りやすい. 勝つか負けるか, よいか 悪いか, ほめられるかけなされるかという自己評価 であり, オセロの石が反転するかのように白黒の二 分的評価となる，換言すれば，他者からの評価に 過敏な状態であり, ときに「根拠のない万能感」を 示すかと思えば, 難しい課題には緊張し, 他者の視 線を意識して，おどおどした様子となる。こういう 子どもに対して「ほめる」行為は, その場での即効 性は認められるものの, 評価への過敏性のステー ジから抜け出すことができない. それは，ほめると いう行為が評価行為であるからだ.

どの子どもに対しても，心を込めてほめることは もちろん大事なことである. しかし，それが子ども の行動をマネジメントする目的をもって行われる 場合, つまり, 下心のある「ほめる」行為であれば,
評価への過敏性をさらに強める.

大切なことは, 他者からの評価以上に重要な価 值をみつけることだ。やってみたいこと, 取り組ん でみたいことをみつけ，その中で成長する自己を発 見することである．時系列において，だんだんと変 わっていく自己に手応えを感じることを形成的自 己評価と呼ぶが, 精神発達的に 5,6 歳の段階にあ る子どもたちにはこの準備ができている. それが 「他者からの評価」に過敏になっているのは, むし ろ即効性を志向した悪しき教育の結果といえる.

学校で取り組まれる教育は, 人類が次の世代に 伝えるべき文化, 科学, 芸術を体系的に組織したも のであり, 子どもたちはそれを習得, 内在化する過 程で自らをつくりかえていく，だんだんと価值づい ていく自己を発見する過程が形成的自己評価であ るが, このステージでの自己変革こそが求められて いる. 学校教育は, 本来的に, この発達要求に応 える社会資源であろう。例えば, 陶芸に真剣に取 り組む姿や, 修学旅行のリーダーとして活躍する様 子には「ほめてほしい」という要求は姿を潜め, 集 団の中で役に立つ手応えと, 過去の自己とは異な る「成長した自己」への自信がみられるはずだ.

もちろん, 二分的自己評価の強い子どもたちに とって, 文化, 科学, 芸術に挑戦することは容易な ことではない. 集団活動, 自治活動, 学校行事な どにも心理的抵抗が強く, 学校教育そのものへの 忌避感が強固に形成されている. 授業づくりは困 難を極めるが, だからといって, 当面の行動コント ロールのみが教育課題として意識され，「いい子で いる」ことが期待されるようでは,「いい子でいら れない」子には不登校を選ぶ道がみえてくるといえ る. 理想論のように聞こえるかもしれないが, 子ど もたちが, わかる内容をわかる方法と条件で教えら れ, 文化, 科学, 芸術を習得する中で自己変革を行 うという営みがない限り学校教育は成立せず, そこ には多かれ少なかれ不登校の危機が存在すると考 
えられる。

9〜10 歳の発達は, 一方で, 自己客観視（セルフ モニタリング）の力も形成する. 小学校低学年と は異なり，自己の「問題」を自覚する時期でもある. 多動や社会的不適応が指摘されると, 自分なりに 心当たりが生まれてくる．この時期に「自分を見 捨てない人」「信頼してくれる大人」が存在するか 否かが重要である，家族だけでなく，学校教育に はそれに応えるだけの寞容さが切実に求められて いる.

\section{文 献}

1) 岡本夏木：9歳の壁 (critical period 【problems】at nine-year). 発達心理学辞典（岡本夏木, 清水御代
明, 村井潤一 監)。ミネルヴァ書房, 京都, 1995

2) 藤井克美：9 歳の壁. 特別支援教育大事典（茂木俊 彦 編集代表)。旬報社，東京，2010

3) 三木裕和 : 知的障害と青年期教育一 $\lceil 9 \cdot 10$ 歳の発達 の節目」に挑む人たち，七転び八起きの「自分づくり」 一知的障害青年期教育と高等部専攻科の挑戦（鳥取 大学附属特別支援学校 編著, 三木裕和 監). 今井書 店, 鳥取, 2017

4）ウタ・フリス 著, 冨田真紀, 清水康夫, 鈴木玲子 訳 : 心理化研究の進展. 新訂 自閉症の謎を解き明かす. 東京書籍, 東京, 2009 ; pp 178-179

5) 別府 哲：自閉症スペクトラムの機能連関, 発達連 関による理解と支援. 障害者問題研究 $2014 ; 42$ ：9199

6) 国立特別支援教育総合研究所: 研究 1 知的障害教 育における「育成を目指す資質・能力」についての具 体的検討. 基幹研究 知的障害教育における「育成 すべき資質・能力」を踏まえた教育課程編成の在り方 一アクティブ・ラーニングを活用した各教科の目標 · 内容. 学習評価の一体化 (平成 27 年度 28 年度) 2017 ; p13 